\title{
Observations on possible life cycle stages of the dinoflagellates Dinophysis cf. acuminata, Dinophysis acuta and Dinophysis pavillardi
}

\author{
Brigitte R. Berland $^{1, *}$, Serge Y. Maestrini ${ }^{2}$, Daniel Grzebyk ${ }^{1}$ \\ ${ }^{1}$ Centre d'Océanologie de Marseille (CNRS URA 41), Station marine d'Endoume, Chemin de la Batterie des Lions, \\ F-13007 Marseille, France \\ ${ }^{2}$ Centre de Recherche en Ecologie Marine et Aquaculture de L'Houmeau (CNRS-IFREMER), BP 5, \\ F-17137 L'Houmeau, France
}

\begin{abstract}
Some aspects of the life-cycle have been investigated in Dinophysis cf. acuminata, the dominant species of the genus along the French Atlantic coast, as well as in D. acuta; a few observations have also been made on the Mediterranean species $D$. pavillardi. Dinophysis cells occur in 2 clearly distinguished sizes. Small cells typically had a theca thinner than large cells, and cingular and sulcal lists were less developed. Both small and large cells were seen dividing, producing 1 to 4 round intracellular bodies. Some of these round bodies in turn contained many small flagellated cells which escaped through a pore and swam rapidly. Their behaviour after release, and how they might give rise to vegetative cells, has not been observed thus far; we do not believe they are fungal parasites. We propose the following hypothesis to explain our observations: round-shaped bodies, formed inside the vegetative cells, produce small, motile zoids. These zoids grow and are transformed into apparently vegetative forms, which later act as gametes. Soon after conjugation, the zygote encysts, sometimes after the first or the second division. This working hypothesis, however, requires further elucidation and confirmation using different approaches.
\end{abstract}

KEY WORDS: Dinophysis sp. · Life cycle · Cyst

\section{INTRODUCTION}

Although the dinoflagellate genus Dinophysis has been known since 1840, when Ehrenberg first described several species, its biology and ecophysiology are still poorly understood.

The harm caused by diarrheic toxins which Dinophysis spp. produce appears to have recently shown a considerable increase both in space and time (Anderson 1989, Smayda 1990, Belin 1993, Hallegraeff 1993). Furthermore, cell densities of $>10^{5}$ cells $1^{-1}, 2$ orders of magnitude higher than those mentioned in the old literature, have recently been reported from different regions of the world (Freudenthal \& Jacobs 1991, Belin 1993, Lassus et al. 1993, Subba Rao et al. 1993). Consequently, increasing attention is now being focused on the life cycles, reproductive strategies, nutrition, toxin production and taxonomy of Dinophysis spp. using

\footnotetext{
•E-mail: berland@com.univ-mrs.fr
}

newly developed methods. Identification of different taxa as well as different stages within species is an important aspect of dinoflagellate ecology, since either spatial or temporal species succession may be partly triggered by mechanisms maintaining the species' capacity to adapt to environmental changes and thus also affect their biological diversity.

That no Dinophysis species have yet been cultured in the full sense, coupled with their sporadic occurrence in the sea, has so far seriously limited current knowledge. Nonetheless, Reguera et al. (1990) described cells of 2 distinct sizes that Mackenzie (1992) later referred to different stages of a sexual life cycle, while Bardouil et al. (1991) observed formation of cysts which they believed to represent a temporary resistant stage.

Here we report some new forms observed in natural populations of Dinophysis cf. acuminata and D. acuta, 2 dominant species along the French Atlantic coast, and $D$. pavillardi, a species occurring in the Mediterranean Sea. 

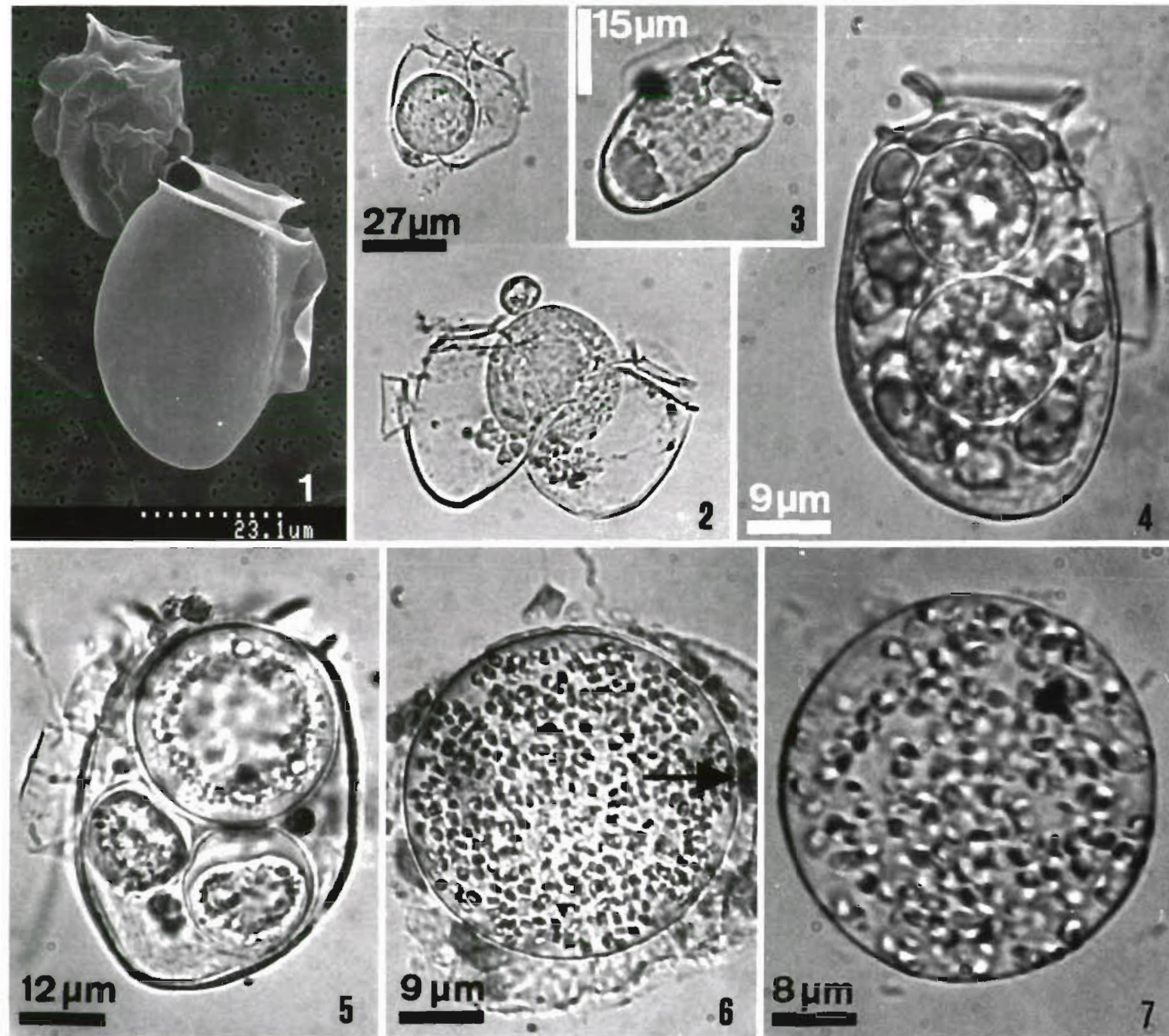

$9 \mu m$
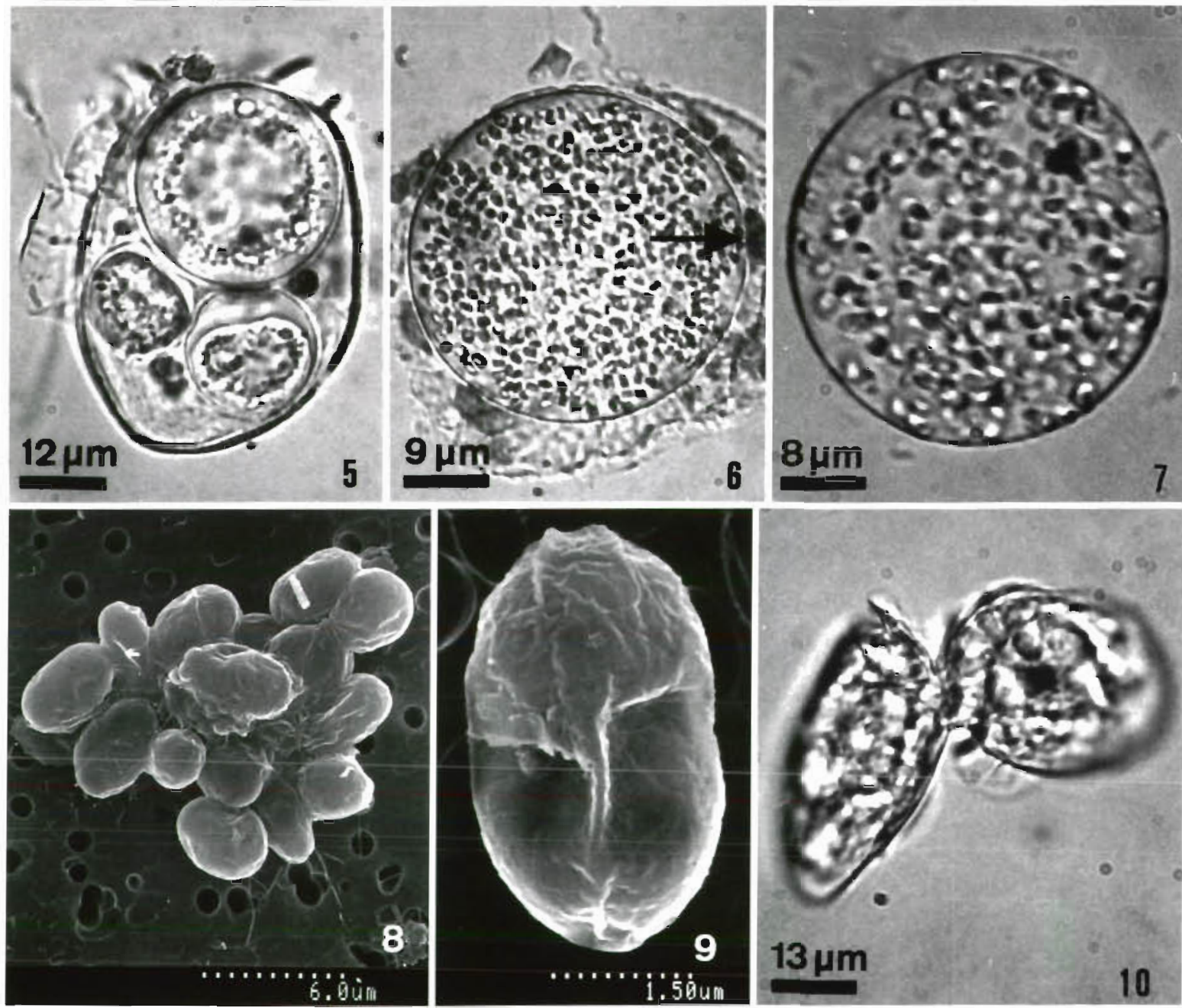

Figs. 1 to 10. Dinophysis cf. acuminata. Fig. 1. Scanning electron microscope image of large and small cells. Fig. 2. Large and small cells freeing a cyst by dehiscence. Fig. 3. Light microscope view of a small cell. Figs. 4 \& 5 . Cells with forming cysts. Figs. 6 \& 7. Free cysts, with zoids inside. In Fig. 6 , the pore can be seen on the right (arrow). Fig. 8. Scanning electron microscope image of several zoids. Fig. 9. Scanning electron microscope image of 1 zoid. Fig. 10. Conjugation of 2 cells 


\section{MATERIAL AND METHODS}

The port of Antifer, near Le Havre, France, provides exceptionally good conditions for collecting Dinophysis spp. cells, since high densities, up to 160000 cells $\mathrm{I}^{-1}$, have occurred in summer nearly every year since 1987 (Lassus et al. 1993). The dominant species is similar to D. acuminata (Fig. 12), though it is likely to be a different, undescribed species (Lassus \& Bardouil 1991). In July and August 1990 and 1992, we harvested a large number of cells using a protocol for concentration by size fractionation and reverse sedimentation (Maestrini et al. 1995 - this issue). In 1992, cells of $D$. pavillardi were collected in the Gulf of Fos, in the Mediterranean Sea. In 1993, cells of D. acuta were harvested in the harbor of Douarnenez, southern Brittany, where a bloom of this species occurred in May. All Dinophysis-enriched assemblages were kept in original seawater (10 l polycarbonate bottles) in subdued daylight, without any shaking or turbulence, at $18^{\circ} \mathrm{C}_{i}$ some Dinophysis populations survived up to $3 \mathrm{wk}$.

Light microscopy. Living and fixed ( $2 \%$ glutaraldehyde) cells were observed with a Leitz optical microscope. For scanning electron microscopy, fixed specimens were gently filtered and rinsed with distilled water and dehydrated through ethyl alcohol $(30,50,70$ and $100 \%)$; then the filters were mounted on scanning stubs, freeze dried and coated with a gold palladium alloy.

Transmission electron microscopy. Cells were first fixed in a mixture of glutaraldehyde and cacodylate (seawater, 5 vols.; glutaraldehyde $25 \%, 1$ vol.; cacodylate buffer $0.4 \mathrm{M}, 4$ vols.) at $4^{\circ} \mathrm{C}$, for $2 \mathrm{~h}$; then cells were rinsed in a mixture of $0.2 \mathrm{M}$ cacodylate and $0.4 \mathrm{M} \mathrm{NaCl}$ for $2 \mathrm{~h}$, followed by 2 rinses with seawater; cells were finally postfixed with $2 \%$ osmic acid for $1 \mathrm{~h}$, and rinsed twice with seawater and several times with distilled water. Fixed samples were dehydrated through a graded ethanol series, embedded in 'Durcupan' resin and sectioned; before observation, thin sections were stained with uranyl acetate.

Fig. 11. Dinophysis cf. acuminata. Transversal section of a small-size, thin-theca cell, at the flagellar pore level, showing the tongue-like organelle (indicated by a large arrow), and a fraction of 1 large cell

\section{RESULTS}

Cells of 2 different sizes were observed in Dinophysis cf. acuminata (Figs. 1 \& 2); the smaller cells resembled D. skagii Paulsen. After 1 to $2 \mathrm{wk}$ in the laboratory, small cells had increased in number; both large and small cells were seen dividing. Usually small cells had a theca thinner than large cells (Fig. 11), and less developed cingular and sulcal lists (Figs. 1, 2 \& 3). Both large and small cells were also observed in $D$. pavillardi (Fig. 14). In D. acuta, we also observed a contraction of the cytoplasm inside the theca, resulting in formation of a small cell inside a large cell (Fig. 15).

One to two wk after sampling, most of the cells, both large and small, were seen to have produced 1 or several internal spherical bodies of varying sizes (Figs. 2, 4,5 \& 13), up to 4 in Dinophysis acuta. Only a fraction of the cytoplasm contributed to the formation of these bodies; hence, when cells disrupted and the round bodies were released, a part of the cell material was released into the water. The outer wall of the round bodies was smooth.

Some round bodies were filled with numerous small granula (Figs. 6 \& 7) showing a colored area. These granula appeared to move and escape from the round

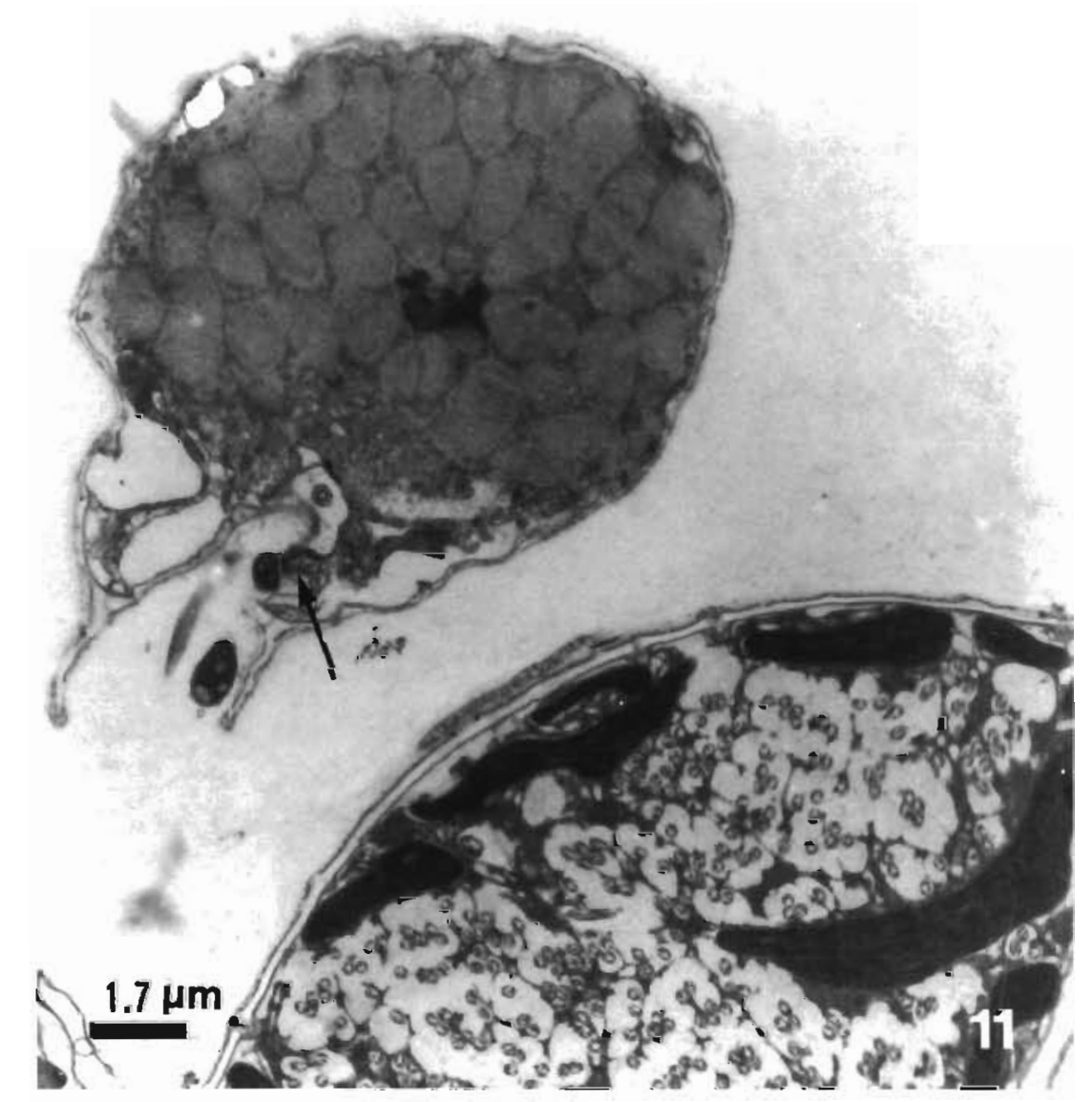



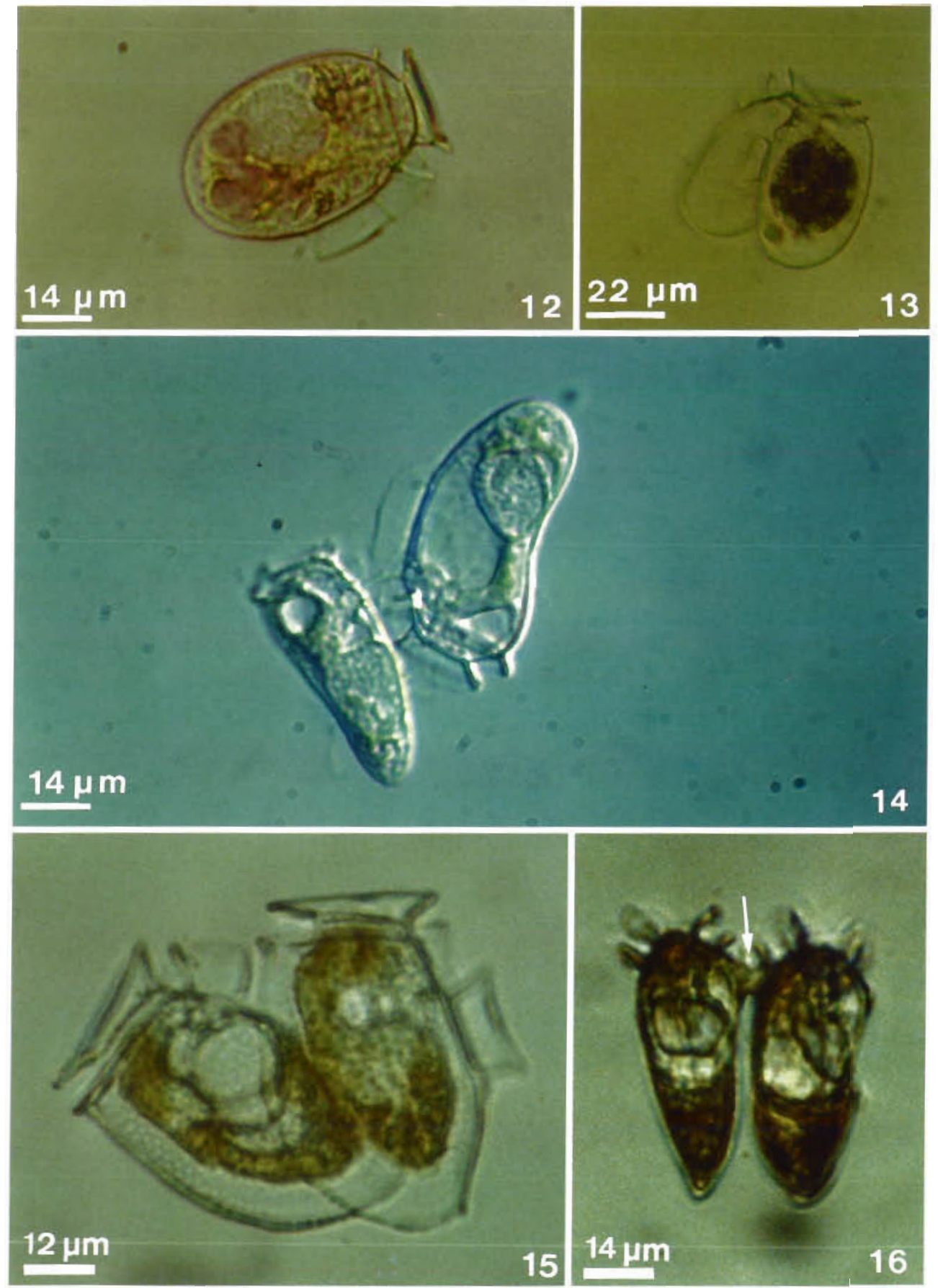

Figs 12 to 16 . Dinophysis spp. Fig. 12. Vegetative cell of $D$. cf. acuminata. Fig. 13. Cell of $D$. cf. acuminata, with 1 cyst inside. Fig. 14. Conjugation of 1 small and 1 large cell of $D$. pavillardi, strongly attached by lists (vigorous shaking with a micropipette was not able to separate the cells). Fig. 15. Small cells of $D$. acuta forming in large cells. Fig. 16. Coupled formation of 2 cells of $D$. acuta, with a bridge shown by the arrow bodies through a pore (Fig. 6). Then, they were seen as flagellated, rapidly swimming, pyriformic cells, $2 \mu \mathrm{m}$ wide and $3 \mu \mathrm{m}$ long (Figs. 8 \& 9). The flagella seemed to be inserted in the anterior part of the cell; they were not clearly seen, however. Unfortunately, most of these cells were immediately captured and ingested by ciliates, and no further observation has yet been possible.

With all 3 species, we have observed images which resembled steps in conjugation, either between cells of the same size (Figs. $10 \& 16$ ) or between one large and one small cell (Fig. 14). Two cells first come together, and used their lists and flagella to wrap around each other (Fig. 14). Later the cells appear to be strongly attached near the sulcal area (Figs. $10 \& 16$ ). They always move together very fast; hence, to enable pictures to be taken, they had to be pipetted and transferred into a few drops of seawater and fixed with glutaraldehyde; this treatment did not separate the 2 cells. We were not able to observe the whole process in a single pair of cells, however. 


\section{DISCUSSION}

Several Dinophysis species have been reported to show cells of 2 distinct sizes, each of which was previously described as a separate species. Accordingly, the following pairs of former species are now associated D. sacculus and D. skagii (Bardouil et al. 1991), D acuta and D. dens (Reguera et al. 1990, MacKenzie 1992, Hansen 1993), D. caudata and D. diegensis (Moita \& Sampayo 1993), D. fortii and D. lapidistrigiliformis (in Bardouil et al. 1991), D. norvegica f. debilor and D. f. crassior (Hansen 1993).

Mackenzie (1992) argued that each size type represents a different gamete in a sexual life cycle, consistent with the anisogamous gamete phenomena observed in some dinoflagellates (Pfiester 1984). The conjugation couplets we observed and the existence of a planozygote with 2 trailing flagella, the result of fusion by 2 cells, seen once by McLachlan (1993) in Dinophysis acuminata, also support the idea that sexual reproduction occurs. In contrast, Partensky \& Vaulot (1989) argued that the 2 size forms of Gymnodinium cf. nagasakiense are not gametes, but reflect a growth strategy; the smaller ones, which use photosynthetic active radiation best, divide faster when environmental conditions are favourable, while the larger ones are more resistant under adverse conditions Historically, this 'depauperating' process was first described by Silva (1971) in several dinoflagellates: without any physiological interpretation, however.

Our findings indicate that both the large and the small cells are capable both of vegetative division and of forming round bodies; we suggest that these round bodies result from sexual reproduction. In other words, small cells should not be solely considered as gametes: they could act both as vegetative and sexual cells, according to the life cycle stage. This process would reflect a high flexibility of the life cycle and ability to cope with changes in environmental conditions.

Cysts formed by Dinophysis spp. were first observed by Bardouil et al. (1991) who believed they were a temporary, resistant stage. Then, Moita \& Sampayo (1993) argued that small cells in $D$. acuta $(D$. dens) and $D$. tripos or $D$. caudata ( $D$. diegensis) were gametes, and that the resulting zygote was identical to the 'resting cyst stage'. In their fixed samples of natural populations, the different forms intermediate between a typical vegetative cell and a cyst were separated only by gradual differences, perhaps suggesting an encystment. According to these authors, the encystment process seemed to begin with the disappearance of the cingular and sulcal lists followed by the production of an outer membrane. The cysts were oval.

The formation of intracellular round bodies which themselves can produce many small motile cells
(Figs $8 \& 9$ ) is reported for the first time. We saw this ephemeral phenomenom 3 times in Dinophysis cf. acuminata, always during the same period of the year, late August. These round-shaped bodies resembled cysts described by Faust $(1990,1993)$ for different species of Prorocentrum. Similar bodies have been also seen in other algae, including the toxic diatom Nitzschia pungens (Subba Rao et al. 1991).

It has been suggested that zoid-like bodies seen in dinoflagellates could be fungal parasites, such as chytrids (Rosowski et al. 1992), and freshwater dinoflagellates of the genera Ceratium and Peridinium have indeed been reported to be infected by chytridiales (Canter 1961, 1968). In contrast, in none of the Dinophysis cf. acuminata and D. acuta we observed did we see any sporangia or zoospores on the thecae (in the zoosporic fungi, sporangia are epibiotic rather than endobiotic) or any thread-like rhizoidal system inside the cell typical of chytrids (Canter \& Jaworski 1978). The ultrastructure shown in the micrographs of $D$. cf. acuminata sampled $1 \mathrm{wk}$ before the formation of round bodies did not indicate infestation by fungi or any other organisms

Many dinoflagellates are known to parasitize marine protists and metazoans (Cachon 1964, Cachon \& Cachon 1967). Fritz \& Nass (1992) showed the presence in Dinophysis norvegica of the endoparasite dinoflagellate Amaebophrya ceratii, which was previously known to parasitize Gonyaulax catenella (Taylor 1968). However, all the sections we have observed in $D$. cf. acuminata and $D$. acuta differed markedly from the trophont given by $A$. ceratii in the host cell (Figs. 13 \& 14 in Fritz \& Nass 1992). Moreover, the cyst-containing Dinophysis cells never differed from the vegetative cells, while trophont-hosting $A$. ceratii cells become giant (Taylor 1968). In contrast, Dinophysis cf. acuminata zoids somewhat resembled motile zoids of the non-cyst-forming dinoflagellate Noctiluca miliaris which were assumed by Zingmarck (1970) to be gametes capable of conjugating and of giving a zygote.

To tentatively summarize: due to the lack of serial observation of the whole process, several hypotheses can be proposed to explain the images we have observed. Although at present the parasite hypothesis cannot be discarded, we prefer the following one. Round bodies form inside the vegetative cells, and produce small, motile zoids; these zoids could be gametes, except that conjugation of zoids was not observed while conjugation of vegetative-shaped cells was clearly seen (Figs. 10, $14 \& 16$ ). Hence, it is likely that zoids grow and give apparently normal vegetative Dinophysis cf. acuminata and $D$. acuta forms, which later act as gametes. Soon after conjugation, the zygote encysts, sometimes after the first or the second division. 


\section{CONCLUSION}

Dinophysis cf. acuminata and Dinophysis acuta may have a sexual reproduction and a life cycle different from those already known for dinoflagellates. The presence of 1 or several zoid producing bodies, if later confirmed, is new for these organisms. Lack of available culture has hitherto prevented observation of successive stages and timing of the gametogenesis; hence further experiments are needed, including DNA measurement and transmission electron microscopy. Full reconstruction of their life cycle, as well as a better knowledge of their nutritional regime, could perhaps be useful in developing culture methods.

Acknowledgements. This study was supported by the 'Programme National Efflorescences Algales Toxiques'. We warmly thank Captain Cirot, M. Ferme and their teams for help during sampling at Antifer, and Dr Ian Jenkinson (ACRO, La Roche Canillac) for improving the English version.

\section{LITERATURE CITED}

Anderson DM (1989) Toxic algal blooms and red tides: a global perspective. In: Okaichi T, Anderson DM. Nemoto $T$ (eds) Red tides: biology, environmental science, and toxicology. Elsevier Sci Pub, New York, p 11-16

Bardouil M, Berland B, Grzebyk D, Lassus P (1991) L'existence de kystes chez les Dinophysales. C r Acad Sci Paris, sér III 312:663-669

Belin C (1993) Distribution of Dinophysis spp. and Alexandrium minutum along French coasts since 1984 and their DSP and PSP toxicity levels. In: Smayda TJ, Shimizu Y (eds) Toxic phytoplankton blooms in the sea. Proc 5th Int Conference on Toxic Marine Phytoplankton, 28 Oct1 Nov 1991. Newport, USA. Elsevier Sci Pub, New York, p $469-474$

Cachon J (1964) Contribution à l'étude des Péridiniens parasites. Cytologie, cycles évolutifs. Ann Sci nat Zool 12ème sér VI:1-158

Cachon J, Cachon M (1987) Parasitic dinoflagellates. In: Taylor FJR (ed)The biology of dinoflagellates. Blackwell Sci Pub, Oxford, p 571-610

Canter HM (1961) Studies on British chytrids. XVIII. Further observations on species invading planktonic algae. Nova Hedwigia 3:73-78

Canter HM (1968) Studies on British chytrids. XXVIII. Rhizophydium mobile sp. nov. parasitic on the resting spore of Ceratium hirundella D.F. Müll. from the plankton. Proc Limn Soc Lond 179:197-201

Canter HM, Jaworski GHM (1978) The isolation, maintenance and host range studies of a Chytrid Rhizophydium planktonicum Canter emend., parasitic on Asterionella formosa Hassall. Ann Bot 42:967-979

Faust MA (1990) Cysts of Prorocentrum marinum (Dinophyceae) in floating detritus at Twin Cays, Belize mangrove habitats. In: Granéli E, Sundström B, Edler L, Anderson DM (ed) Toxic marine phytoplankton. Proc Fourth Int Conference Toxic Marine Phytoplankton, 26-30 June 1989, Lund, Sweden. Elsevier Pub, New York, p $138-143$

Faust MA (1993) Sexuality in a toxic dinoflagellate, Prorocen- trum lima. In: Smayda TJ, Shimizu Y (eds) Toxic phytoplankton blooms in the sea. Proc 5th Int Conference on Toxic Marine Phytoplankton, 28 Oct-1 Nov 1991, Newport, USA. Elsevier Scl Pub, New York, p 121-126

Freudental AR, Jacobs J (1991). Observations on Dinophysis acuminata and Dinophysis norvegica in Long Island waters: toxicity, occurence following diatom-discolored water and co-occurence with Ceratium. In: Smayda TJ (ed) Abstract 5th Int Conference on Toxic Marine Phytoplankton, Oct 28-Nov 1 1991, p. 45

Fritz L, Nass M (1992) Development of the endoparasitic dinoflagellate Amaebophrya ceratii within host dinoflagellate species. J. Phycol 28(3):312-320

Hallegraeff GM (1993) A review of harmful algal blooms and their apparent global increase. Phycologia 32(2):79-99

Hansen G (1993) Dimorphic individuals of Dinophysis acuta and $D$. norvegica (Dinophyceae) from Danish waters. Phycologia 32(1):73-75

Lassus P, Bardouil M (1991) Le complexe 'Dinophysis acuminata': identification des espèces le long des côtes françaíses. Cryptogam Algol 12(1): 1-9

Lassus P, Proniewski F, Maggi P, Truquet P, Bardouil M (1993) Wind-induced toxic bloms of Dinophysis cf. acuminata in the Antifer area (France). In: Smayda TJ, Shimizu Y (eds) Toxic phytoplankton blooms in the sea. Proc 5th Int Conference on Toxic Marine Phytoplankton, 28 Oct-1 Nov 1991, Newport, USA. Elsevier Sci Pub, New York, p $519-523$

Mackenzie L (1992) Does Dinophysis have a sexual life cycle? J Phycol 28:399-406

Maestrini SY, Berland BR, Grzebyk D, Spano AM (1995) Dinophysis spp. cells concentrated from nature for experimental purposes, using size fractionation and reverse migration. Aquat microb Ecol 9:177-182

McLachlan JL (1993) Evidence for sexuality in a species of Dinophysis. In: Smayda TJ, Shimizu Y (eds) Toxic phytoplankton blooms in the sea. Proc 5th Int Conference on Toxic Marine Phytoplankton, 28 Oct-1 Nov 1991. Newport, USA. Elsevier Sci Pub, New York, p 143-146

Moita MT, Sampayo MA de M (1993) Are there cysts in the genus Dinophysis? In: Smayda TJ, Shimizu Y (eds) Toxic phytoplankton blooms in the sea. Proc 5th Int Conference on Toxic Marine Phytoplankton, 28 Oct-1 Nov 1991, Newport, USA. Elsevier Sci Pub, New York, p 153-157

Partensky F, Vaulot D (1989) Cell differentiation of the bloomforming dinoflagellate Gymnodinium cf. nagasakiense J Phycol 24(3):408-415

Pfiester LA (1984) Sexual reproduction. In: Spector DL (ed) Dinoflagellates. Acad Press, London, p. 181-199

Reguera B, Bravo I, Fraga S (1990) Distribution of Dinophysis acuta at the time of a DSP outbreak in the rias of Pontevedra and Vigo (Galicia, NW Spain). Comm Meet Int Coun Explor Sea CM-ICES/L.14, $12 \mathrm{p}$

Rosowski JR, Johnson LM, Mann DG (1992) On the report of gametogenesis, oogamy, and uniflagellated sperm in the pennate diatom Nitzschia pungens (1991; J Phycol 27 21-26). J Phycol 28(4):570-574

Silva ES (1971) The 'small' form in the life cycle of dinoflagellates and its cytological interpretation. In: Farinacci A (ed) Proc 2nd Plankton Conference, Roma, 1970, Techniscienza, p 1157-1167

Smayda TJ (1990) Novel and nuisance phytoplankton blooms in the sea: evidence for a global epidemic. In: Granéli E, Sundström B, Edler L, Anderson DM (ed) Toxic marine phytoplankton. Proc 4th Int. Conference Toxic Marine Phytoplankton, 26-30 June 1989, Lund, Sweden. Elsevier Pub, New York, p 29-40 
Subba Rao DV, Partensky F, Wohlgeschaffen G, Li WKW (1991) Flow cytometry and microscopy of gametogenesis in Nitzschia pungens, a toxic-forming, marine diatom. J Phycol 27(1):21-26

Subba Rao DV, Pan Y, Zitko V, Bugden G, Mackeigan K (1993) Diarrhetic shellfish poisoning (DSP) associated with a subsurface bloom of Dinophysis norvegica in Bedford
Basin, eastern Canada. Mar Ecol Prog Ser 97:117-126

Taylor FJR (1968) Parasitism of the toxin-producing dinoflagellate Conyaulax catenella by the endoparasitic dinoflagellate Amaebophyra ceratii. J Fish Res Bd Can 25(10): 2241-2245

Zingmark RG (1970) Sexual reproduction in the dinoflagellate Noctiluca miliaris Suriray. J Phycol 6:122-126 